\title{
Editorials
}

\section{Understanding and responding to demand in English general practice}

\section{INTRODUCTION}

Two Parliamentary Select Committees have recently focused on the future of primary care in England. On 30 July 2015, the Health Committee initiated an inquiry into the challenges affecting primary care services ${ }^{1}$ and, 4 months later, the Public Accounts Committee launched its own review of access to general practice in England. ${ }^{2}$ Extensive evidence has been submitted to both Committees revealing a broad consensus about the need for significantly increased investment. Yet these exercises have also highlighted a regrettable lack of detailed understanding about the volume and nature of current activity in English general practices. This lacuna calls into question the quality of the decision-making processes and risks a misallocation of the extra funding that is promised.

\section{THE EMERGING CONSENSUS}

There is broad agreement among the stakeholders who have contributed to the inquiries that: (a) the share of NHS funding directed to general practice in England has declined in recent years (from nearly $11 \%$ in 2005-2006 to 7.2\% in 2016-2017);,3.4 (b) the workload has increased substantially: ${ }_{i}^{5}$ (c) patient satisfaction with access has declined in recent years (falling from $80 \%$ being quite or very satisfied with their practice in 2009 to $69 \%$ in 2015); ${ }^{6}$ and (d) at least 5000 additional GPs plus other general practice staff are needed.?

\section{EVIDENCE GAPS}

Addressing these issues rationally is made significantly more difficult as a result of some remarkable gaps in our knowledge. Despite the insights into general practice workload provided by Professor Richard Hobbs and his team, ${ }^{8}$ we still do not know how many people access English general practices each year. The National Audit Office recently described the situation as follows:

No national data are currently collected on the number, complexity, or reasons for consultations in general practice. This means the Department and NHS England, as well as local commissioners, do not have a robust understanding of the demand for services."

Moreover, the 2015 report of the Primary

\section{"It is particularly striking that we don't even know the relative weight of the potential causes of the apparent recent increases in workload.}

Care Workforce Commission noted that our understanding of supply is equally deficient:

'Planning in primary care is difficult because of the lack of reliable systematic data about the numbers of different disciplines in primary care, who currently does what, and whether they have the appropriate skills to deliver the wide range of functions that are needed. '10

\section{THE IMPORTANCE OF UNDERSTANDING DEMAND}

The findings of research to understand demand would have fundamentally important implications for the future workforce configuration within English general practice. We don't just want to know how many people are accessing, or would like to access, their GP surgery. We need to know what they needed (or wanted) and who could best provide help. We also need to know how much time they needed with the relevant staff member so that the implications of increasing complexity and comorbidity can be properly assessed.

As well as quantifying demand, we need to capture how patients were dealt with by the practice (for example, face to face, telephone, or home visit) and whether a different interface would have been preferable from the point of view of safety, clinical effectiveness, and an improved patient experience. We also should review which triage techniques are adopted in different settings. This analysis is crucial to inform the potential use of alternatives to traditional consultation methods which, in turn, have major workload and IT implications.

It is particularly striking that we don't even know the relative weight of the potential causes of the apparent recent increases in workload. Plausible explanations include the more complex needs of an ageing population, shifting services out of hospitals, meeting Quality Outcome Frameworks (QOF) and Enhanced
Service targets, underinvestment in social and community care, expanding list sizes, consultations on non-health matters, and increased bureaucracy. Different policy responses are appropriate to address each of these factors and ignorance of their relative importance is a major flaw.

Consistent with the argument above, the Public Accounts Committee recommended in March 2016 that the Department of Health and NHS England should publish a plan that makes clear how they will improve the information that is available on demand, activity, and capacity in general practice. ${ }^{2}$

In order to address the knowledge gaps identified above, I contend that this plan will need to move beyond existing sources, such as clinical systems and national patient surveys. Large scale retrospective research, although valuable, is only able to capture what happened and not, crucially, what could or should have happened. This requires a major research initiative, in keeping with the objective of effectively managing a multibillion pound activity.

\section{STRUCTURAL MATTERS}

We now turn to a second issue that is brought into sharp relief by the issues discussed above. Assume that comprehensive research is carried out and that it is sufficiently detailed to provide clear messages for practices on crucial questions such as: (a) the optimum number of GP and nursing hours; (b) the most sensible balance of face-to-face and telephone consultations; and (c) the value of third sector support to patients within the practice setting. Under the current structures, it will be (in most practices) the decision of GP partners whether to adapt their practice in line with such recommendations.

Of course, GP partners are placed in a morally precarious position by the current arrangements. They are asked to make direct choices between their profits and the 


\section{ADDRESS FOR CORRESPONDENCE}

Graham Box

E-mail: drgrahambox@icloud.com quality of care that they offer their patients. The situation is worsened where there are disagreements and frictions within partnerships. In the worst case scenarios, the evidence will be less influential than the self-interest of the decision makers. Indeed, in some settings, a single partner can block improvements in patient care on the grounds that the changes are not consistent with their preferred consulting style.

There are certainly important advantages to the partnership model of managing GP surgeries, but I would suggest that it can be a significant impediment to implementing an objectively determined model of primary care resource allocation. National research would help to define the workforce and systems development that are needed but this then needs to be put in place locally. Failures at either the national or local level risk diluting the potential improvements both in health and in the patient experience.

\section{FINAL REFLECTIONS}

Professor Maureen Baker, current chair of the Royal College of General Practitioners (RCGP) has been very frank about the extreme pressures facing English general practice:

.... if you really look at the safety of patients and what is important in practices, almost certainly the biggest factor in patient safety in general practice at the moment is doctor fatigue. Doctors who are stressed, overworked, exhausted or worried are much more liable to be doctors who make mistakes. '11

Simon Stevens, the Chief Executive of NHS England, also acknowledges the urgency of the current challenges:

'Because people's backs are against the wall, they are now willing to contemplate doing things quite differently in primary care, and if we can provide the resourcing and some of the support for that, I think we will see quite substantial change over the next 24 to 36 months. That is what GPs want. They don't just want something on the never-never, 5 years out; they want to see the cavalry arriving now, and it is our collective job to bring that about.' 12

It is crucial that lessons are learned about how and why the provision of English primary care has deteriorated to the extent described by such senior individuals. Part of that process should include questioning whether the necessary structures are in place to understand the prevailing pressures and activity and also to both identify and implement effective solutions. Whatever

\section{REFERENCES}

1. House of Commons Health Committee. Primary care. Fourth report of session 2015-16 [HC408] House of Commons, April 2016.

2. House of Commons Committee of Public Accounts. Access to general practice in England. Twenty-eighth report of session 2015-16. [HC673]. House of Commons, March 2016.

3. Royal College of General Practitioners. Written evidence submitted by the RCGP (PRI0174). 2015. http://data.parliament.uk writtenevidence/committeeevidence.svc/ evidencedocument/health-committee/primary care/written/20769.pdf (accessed 25 Jul 2016).

4. NHS England NHS England Board Paper. Allocation of resources to NHS England and the commissioning sector for 2016/17 to 2020/21. https://www.england.nhs.uk/ wp-content/uploads/2015/12/04.PB_.17.12.15Allocations.pdf (accessed 25 Jul 2016).

5. Local Government Association and the Association of Directors of Adult Social Services. Written evidence submitted by the Local Government Association and Association of Directors of Adult Social Services (PRI0070). LGA and NHS Confederation, 2015. http://data.parliament.uk/writtenevidence/ committeeevidence.svc/evidencedocument/ health-committee/primary-care/written/20332 html (accessed on 28 July 2016).

6. Appleby J, Robertson R. Public satisfaction with the NHS in 2015. Results and trends from the British Social Attitudes survey. The King's Fund, 2016. http://uww.kingsfund.org.uk/sites/ files/kf/BSA-public-satisfaction-NHS-KingsFund-2015.pdf (accessed 26 Jul 2016). their strengths, it should be acknowledged that the current arrangements allow an unfortunate combination of vices: national policymaking that is not evidence-based and local implementation that is not patient-centred.

\section{Graham Box,}

Independent researcher, Berkshire, UK.

\section{Provenance}

Freely submitted; externally peer reviewed.

DOI: 10.3399/bjgp16X686701

7. Department of Health, NHS England and Health Education England. Written evidence submitted by the Department of Health, NHS England and Health Education England [PRIO200]. 2015. http://data.parliament.uk/ writtenevidence/committeeevidence.svc/ evidencedocument/health-committee/primarycare/written/21020.pdf laccessed 26 Jul 2016).

8. Hobbs, FDR, Bankhead C, Mukhtar T, et al. Clinical workload in UK primary care: a retrospective analysis of 100 million consultations in England, 2007-14. Lancet 2016; 387(10035): 2323-2330.

9. National Audit Office. Stocktake of access to general practice in England. 2015. https:// uww.nao.org.uk/wp-content/uploads/2015/11/ Stocktake-of-access-to-general-practice-inEngland.pdf (accessed 26 Jul 2016).

10. Primary Care Workforce Commission. The future of primary care: creating teams for tomorrow. 2015. https://www.hee.nhs.uk/sites/ default/files/d\}ocuments/The\%20Future\%20 of\%20Primary\%20Care\%20report.pdf laccessed 26 Jul 2016).

11. Baker M. Oral evidence given to the Health Committee Inquiry into Primary Care. 2015 http://data.parliament.uk/writtenevidence/ committeeevidence.svc/evidencedocument/ health-committee/primary-care/oral/26114.pdf laccessed 26 Jul 2016).

12. Stevens S. Oral evidence given to the Public Accounts Committee Inquiry into Access to General Practice in England. 2016. http://data.parliament.uk/writtenevidence/ committeeevidence.svc/evidencedocument/ public-accounts-committee/access-togeneral-practice-in-england/oral/26750.pdf laccessed 26 Jul 2016). 